\section{Heterosexual Marriage Trends in the West}

MAKS BANENS

University of Lyon, France

Stable heterosexual marriage patterns in the Western world changed dramatically during the 1960s. Marriage rates dropped, divorce rates went up, and unmarried cohabitation became widespread. Unmarried couples postponed or refused to step into marriage, while married couples seemed eager to step out. These changes occurred shortly after what has been considered in hindsight as the golden age of the nuclear family, when marriage was almost universal and the mean age at first marriage was historically low.

At first, demographers associated marriage postponement with the fall in fertility rates attributable to the spread of the birth control pill and other new contraceptive techniques. Demographers welcomed these changes because reliable family planning was thought to reinforce family cohesion and thus to be favorable to both parents and children. Family values were not initially thought to be in decline. On the contrary, marriages and families were considered to be becoming stronger because of more efficient birth control and better family planning. For the same reasons, easier divorce was welcomed because social investment in "marriage-at-all-costs" came to be widely regarded as overly restrictive, and divorce was gradually considered preferable to confining, abusive, and deeply unhappy marriages.

In the 1980s, though, it became clear that variations in family and marriage patterns could not be explained by changes in the availability of contraceptives alone. Marriage and fertility remained low, divorce and cohabitation kept rising, soon followed by increasing numbers of out-of-wedlock births. In order to explain more comprehensively these demographic shifts, Dirk Van de Kaa and Ron Lesthaeghe (1986) formulated a more extensive theory known as the "Second Demographic Transition" (SDT). They argued that broader cultural and economic factors were supporting the demographic changes. Women's labor force participation, the welfare state, especially support for the elderly, and cultural shifts such as the decline of religion, greater social acceptance of sexual activity outside marriage, and the emergence of post-material aspirations of self-realization were supposed to explain the low fertility, high divorce, and unmarried cohabitation rates. As a concept, the SDT emphasized the unstable character of the new demographic situation. The first demographic transition (mortality and fertility decline) had been characterized by strong population growth, and the second transition announced population decline as fertility rates had dropped below replacement levels in many Western countries. SDT scholarship definitely implied a pessimistic view of the ongoing demographic changes, drawing associations between demographic shifts such as delayed marriage, cohabitation, divorce and out-of-wedlock births, and threats to social cohesion such as broken marriages, child insecurity, and population decline. Many demographers shared these concerns, as did many sociologists. Others, on the contrary, were optimistic, asserting that the heterosexual nuclear family is a product of unequal, heteronormative, patriarchal gender relations and that its cultural supremacy reproduces both women's subordination and compulsory heterosexuality; thus, new family patterns

The Wiley Blackwell Encyclopedia of Gender and Sexuality Studies, First Edition. Edited by Nancy A. Naples.

(c) 2016 John Wiley \& Sons, Ltd. Published 2016 by John Wiley \& Sons, Ltd.

DOI: 10.1002/9781118663219.wbegss376 
would bring more individual satisfaction, personal freedom in intimate relationship formation, and greater tolerance and social protection for a diversity of family forms (Collins 1985; Giddens 1992). Almost 30 years have passed since the formulation of the SDT theory. Demographers and sociologists are still divided on the long-term effects of the new family behavior. Yet, we may try to establish a preliminary overview on recent marriage trends.

\section{MARRIAGE}

Marriage rates were historically high at the beginning of the 1960s throughout Europe and North America (Coontz 2005). They then declined rapidly, but not simultaneously. Sweden and Denmark were the forerunners. In these Northern European countries, marriage rates started to fall in the second half of the 1960s. In Germany, the United Kingdom, the Netherlands, and Switzerland, they began to decline in the early 1970s, in Belgium, France, Spain, Italy, and Canada in the second half of the 1970s, and in the United States around 1980. After 1990, most Eastern European countries had joined the general trend of declining marriage rates.

In most countries, marriage decline was rapid. Total rates dropped from close to 1000 first marriages per 1000 persons to less than 600 per 1000 persons within $15-20$ years. Rates then re-stabilized or very slowly increased, starting in Denmark and Sweden. Those who marry today tend to do so at older ages. Mean age at first marriage increased by about five years in all countries. For men, mean age stabilized at 30-31, for women at $28-29$. Only the United States show significantly lower ages: 28 for men, 26 for women, but US marriage decline is particularly slow and has not yet come to an end.

Since the 1990s, most European and Northern American countries have begun to show a new marriage pattern. A large proportion $(40-50 \%)$ of each generational cohort remains unmarried, and those who do marry do so consistently at older ages than during the mid-twentieth century. As Prioux et al. (2011) showed, in France the rise in mean age at first marriage comes from fewer marriages at young ages, and from more marriages over the age of 30. Additionally, reasons for marrying seem to have changed. At young ages, marriage continues to symbolize long-term commitment and generally occurs before or shortly after first childbirth. At ages over 30, marriage may still symbolize long-term commitment, but it is no longer situated at the beginning of the relationship. At these ages, economic advantages may be more decisive than symbolic commitment.

Economic and other marriage advantages have been reduced dramatically during the last decades. Until the 1970s, many countries offered limited rights to unmarried couples who wanted to rent or purchase a house. In Germany, for instance, house-owners were not allowed to rent to unmarried couples until 1982. Marriage also conditioned legal fatherhood. It conditioned economic and social rights, especially for housewives. Most of these marital privileges have disappeared during recent decades. Marriage rates dropped at the same time. Yet, marriage still has legal consequences. The most significant of these concern the end of marriage: next-of-kin recognition, retirement pensions, succession, and divorce arrangements. They have provided most of the arguments in the debate on same-sex marriage that has occupied the political agenda of many countries since the 1990s and 2000s.

\section{UNMARRIED COHABITATION}

Declining marriage rates have coincided with rising rates of unmarried cohabitation. 
Unlike marriage, cohabitation is not registered by civil administrations and therefore statistics are not well known. Estimates rely on census and survey data, but until 1990, most censuses did not provide information on cohabitation. Over the last decades, most countries introduced specific questions in censuses and surveys so there is now more, and more reliable, data available.

Even though the data may not be complete, there is no doubt that unmarried cohabitation increased rapidly from the 1970s onwards in many countries (Northern Europe, United Kingdom, France, and Canada). Generations born after 1945 started cohabiting before marriage instead of marrying before cohabitation. Demographers called it premarital cohabitation or "trial marriage" and economists considered it as rational behavior (Becker et al. 1977). They argued it would help to prevent unhappy marriages. Marriages after cohabitation, therefore, would be more stable than direct marriages. Yet, the facts refuted this hypothesis. Marriages after cohabitation, paradoxically, showed higher divorce frequencies than direct marriages (Cherlin 1992). This paradox was studied over and over, until Reinhold et al. (2010) proved that there was a selection bias. The first cohabiters were rather different from the rest of their generation in all aspects and marriage instability was related to those aspects rather than to the cohabitation itself. When premarital cohabitation became widespread in more recent generations, the negative relationship with marriage stability disappeared. Yet, Becker's hypothesis of a positive relationship has not been observed so far.

Another question that has widely been discussed by researchers is: Are unmarried cohabitations limited to short-term premarital unions or are a significant number of them long-term alternatives to marriage? Van de Kaa and Lesthaeghe (1986) formulated a two-stage process. During the era when marriage was almost universal, cohabitation would have been largely premarital and then, as marriage became less common and cohabitation more so, cohabitation would have become a long-term alternative to marriage. Recent cohort analysis in the United Kingdom refutes this hypothesis (Beaujouan and Bhrolchain 2011). The increase of long-term cohabitation started in the 1970s. At first, it resembled premarital cohabitation but many of these first generation cohabiters are still unmarried today. What looked like premarital cohabitation was, at least for some, an alternative to marriage right from the start.

It is difficult to describe the role of cohabitation in the family formation process. Heuveline and Timberlake (2004) compared 16 European and North American countries using data from 1990-1991. They found major differences: marginal cohabitation in Spain, Italy, and Poland; more frequent, premarital cohabitation in many Western and Central European countries (Belgium, Switzerland, Czech Republic, Hungary, Austria, Finland, Germany, Slovenia, and Latvia); frequent, short premarital cohabitation in the United States and New Zealand; very frequent, premarital and long-term cohabitation in Canada, France, and Sweden. In this typology, high frequencies are related to long-term cohabitation, but this does not necessarily mean that high frequency of cohabitation coincides with cultural opposition to the institution of marriage itself. In Sweden, half of all births occur out of wedlock, but many of these unmarried parents marry some years later. In France, they do not.

Recent longitudinal research on cohabitation in England and Wales has estimated the repartition of premarital and long-term cohabitation (Wilson 2009; Wilson and Stuchbury 2010). Among all unmarried cohabiting partnerships surviving from 1991 until 2001, one third remained unmarried, two thirds married. These proportions are 
consistent with Swedish data. But in France, the proportion of long-term cohabitation is higher.

Not surprisingly, France has created a legal alternative to marriage: the Civil Pact of Solidarity (Pacs). This relationship recognition scheme, which was originally conceived to provide same-sex couples with marriage-like benefits, includes nearly all of the remaining privileges afforded by marriage, though on slightly less favorable terms, and has proved highly popular with heterosexual couples. In Europe and North America, only two countries have introduced a nation-wide legal alternative to heterosexual marriage, the Netherlands (1998) and France (1999). In legal terms, the Dutch registered partnership is even closer to marriage than the Pacs but Dutch partnership numbers remain far behind Dutch marriage numbers. In France, on the contrary, the Pacs became a popular success: the number of Pacs increased very fast from 1999 until 2010 and seems to have leveled off at about $70 \%$ of the number of marriages. So far, France seems unique in what has been called the "flight from marriage." It is hard to say if France set the standard of a general process or if there will be individual national processes with diverse outcomes. For now, the difference between long-term cohabitation in France - and to a somewhat lesser extent in Canada - and premarital cohabitation in most other countries is associated with childbirth. Raising children does not motivate many French cohabiters to marry, unlike in most other countries. It is not known if this reflects social and economic or symbolic constraints.

\section{CONCLUSION}

Contemporary heterosexual marriage in Western nations is very different from heterosexual marriage 50 years ago. It is no longer universal, no longer a condition for living together as a couple, and no longer the main social arrangement in which children are raised. However, marriage continues to afford economic and social protection as well as social recognition for couples and families, and marriage has not disappeared. At least half of the younger generations are predicted to eventually marry. Legal changes may explain both its decline and its partial continuity. Indeed, for most couples, cohabiting, giving birth and raising children have become independent from marriage in terms of legal rights and protection. At the beginning of a loving relationship, there are no longer any legal incentives for marriage, with the exception of a few countries, such as Italy or the United States, where some social and economic advantages are still exclusively linked to marriage. Therefore most couples nowadays start off by cohabiting rather than marrying. And if they do marry some years later, it seems to be related more to concerns about the end of the relationship where marital status still makes a difference.

Materialist considerations for choosing or not choosing marriage have largely given way to post-materialist aspirations of self-realization, or considerations of individual satisfaction and happiness through the exercise of autonomy and self-expression. Although this does not mean that materialist considerations have become weaker. Economic protection and legal parenthood are still very strong materialist aspirations, but they have been largely disconnected from marriage. There are less "materialist" reasons to marry, at the beginning of a loving relationship and also during the years of raising children. Non-materialist motivations have not necessarily grown stronger, but they do play a bigger role because part of the materialist motivations have faded away. This would seem to explain both the flight from marriage of more than one third of the population 
and the strong emphasis on non-materialist values by those who do marry.

Recently, researchers have worked to adapt elements of SDT theory, especially with regard to gender dynamics and its effects on fertility. Van de Kaa and Lesthaeghe, like many other demographers, found a positive relationship between higher women's labor force participation and lower fertility. For demographers and social scientists concerned with the decline of the nuclear family and maintaining population growth at replacement levels, this positive relationship was one of the most alarming messages of the SDT. Surprisingly, this positive relationship disappeared in the 1990s and became negative in the 2000s. In order to understand the paradoxical effect of women's labor force participation on fertility, Goldscheider and colleagues (2010) distinguished two phases in the recent gender dynamics. During the first phase, women increase labor participation and reduce the professional gender gap, but men do not increase their housework participation. At this stage, fertility is at a very low level. Many European countries are currently at this stage. The second phase starts when men increase their housework participation and, thereby, reduce the gender gap at home. This is thought to favor an increase in fertility.

In the US context, research has described the gap in men's domestic work participation as a "stalled revolution" in gender relations. Since the cultural shifts of women's liberation in the 1960s, men's participation in unpaid domestic work and the general social value placed on the feminized labor of housework and childcare has yet to rival rates at which women have entered the paid workforce or the general social value placed on paid labor (Hochschild and Machung 1989). Indeed, men's continued reliance on women's unpaid household labor - even when women work part- or full-time - and women's fear of being trapped in unequal relationships is thought to be an explanatory mechanism for women delaying or opting out of marriage in US contexts (Gerson 2010).

Though heterosexual marriage demographics, marriage incentives, the rights afforded to married couples, and the social and symbolic meanings of marriage have changed tremendously in Western countries since the 1960s, marriage remains a route to social recognition and protection for many couples and families, as well as a deeply emotional public statement of love and commitment for those who marry. Activist battles for the rights of same-sex couples to access marriage - despite longstanding and ongoing critiques of marriage in queer communities - in many ways reflect the dividing lines in mainstream society. While the future relationship of marriage to family formation, fertility, and social organization generally remains uncertain, it is clear that up to now, marriage as an institution is a powerful organizer of individual and group life for large parts of Western populations.

SEE ALSO: Birth Control, History and Politics of; Family Planning; Fertility Rates; Gender Equality

\section{REFERENCES}

Beaujolai, Eva, and Maire Ni Bhrolchain. 2011. "Cohabitation and Marriage in Britain since the 1970s." Population Trends, 145: 35-59.

Becker, Gary, Elisabeth M. Landes, and Robert T. Michael. 1977. "An Economic Analysis of Marital Instability." Journal of Political Economy, 85(6): $1141-1188$.

Cherlin, Andrew J. 1992. Marriage, Divorce, Remarriage, revised and enlarged edition. Cambridge, MA: Harvard University Press.

Collins, Randall. 1985. Sociology of Marriage and the Family: Gender, Love, and Property. Chicago: Nelson-Hall.

Coontz, Stephanie. 2005. Marriage, a History: From Obedience to Intimacy or How Love Conquered Marriage. New York: Viking.

Gerson, K. 2010. The Unfinished Revolution: How a New Generation is Reshaping Family, Work, and 
Gender in America. New York: Oxford University Press.

Giddens, Anthony. 1992. The Transformation of Intimacy: Sexuality, Love and Eroticism in Modern Societies. Cambridge: Polity.

Goldscheider, Frances, Livia Olah, and Allan Puur. 2010. “Reconciling Studies of Men's Gender Attitudes and Fertility: Response to Westoff and Higgins.” Demographic Research, 22: 189-198.

Heuveline, Patrick, and Jeffrey M. Timberlake. 2004. "The Role of Cohabitation in Family Formation: The United States in Comparative Perspective." Journal of Marriage and Family, 66(5): $1214-1230$.

Hochschild, Arlie, and Anne Machung. 1989. The Second Shift: Working Parents and the Revolution at Home. New York: Viking.
Prioux, France, Magali Mazuy, and Magali Barbieri. 2010. "Recent Demographic Developments in France: Fewer Adults Live with a Partner." Population, 65(3): 363-413.

Reinhold, Steffen. 2010. "Reassessing the Link between Premarital Cohabitation and Marital Instability.” Demography, 47(3): 719-733.

van de Kaa, Dirk, and Ron Lesthaeghe. 1986. "Twee demografische transities?" [Two Demographic Transitions?] Mens en Maatschappij: 9-24.

Wilson, Ben. 2009. "Estimating the Cohabiting Population." Population Trends, 136: 21-27.

Wilson, Ben, and Rachel Stuchbury. 2010. "Do Partnerships Last? Comparing Marriage and Cohabitation Using the ONS Longitudinal Census Data." Population Trends, 139: 37-63. 